\title{
ZAOKRET KAZNENE POLITIKE I SUVREMENI ZATVORSKI SUSTAV U NIZOZEMSKOJ
}

Sažetak:

\begin{abstract}
Ovaj rad bavi se zatvorskim sustavom u Nizozemskoj u svjetlu tamošnjeg zaokreta u kaznenoj politici. Rješavanje gorućeg problema prijeteće prekapacitiranosti u nizozemskim penitencijarnim institucijama nudi odgovor na pitanje koje penolozi postavljaju posljednja tri desetljeća: ulaze li zatvori u novu fazu razvoja $i$ funkcije? Ličnost zatvorenika i njegova psihosocijalna rekuperacija, kao apsolutni fokus i povijesna determinanta filozofije nizozemskih zatvora pada u subordinirani položaj zahtjevima javnosti za sigurnošću društva kao i inzistiranju političkih struktura na rentabilnosti sustava. Koincidiranje političkog zahtjeva rentabilnosti sa suvremenim tehnološkim dostignućima u poljima nadzora i kontrole prvi put u povijesti omogućava široku primjenu ekstramuralnih oblika kažnjavanja, što zatvore čini prijelaznom institucijom u procesu kažnjavanja velike većine osudenika, a kojima se unutar samih institucija reduciraju rehabilitacijski programi. Potpunom i isključivom institucionaliziranju bivaju podvrgnute ograničene skupine zatvorenika osuđenih zbog teških oblika kaznenih djela. U radu se obrađuje povijesna podloga društvenih i političkih zbivanja u Nizozemskoj koji su determinirali novi pravac kaznene politike, a samim tim i karakter tamošnjih zatvorskih institucija. U drugom dijelu rada, navedeni pravac istraživanja nastavlja u smjeru temeljite obrade načina funkcioniranja i strukture suvremenog zatvorskog sustava u Nizozemskoj, uz prikaz funkcioniranja standardnih i eksperimentalnih oblika penitencijarnih programa.
\end{abstract}

Ključne riječi: $\quad$ nizozemski zatvorski sustav, izvršenje kazne zatvora, zatvaranje zatvora u Nizozemskoj, penitencijarni programi

* Dr. sc. Zvonimir Tomičić, docent na Katedri kazneno-pravnih znanosti Pravnog fakulteta Sveučilišta Josipa Jurja Strossmayera u Osijeku, Stjepana Radića 13, 31000 Osijek, Republika Hrvatska. Adresa e-pošte: tomz@pravos.hr. ORCID: https://orcid. org/0000-0001-6159-6475.

** Vladimir Horvat, mag. iur. Prebivalište: Glavna 64, 31309 Kneževi Vinogradi, Republika Hrvatska. Adresa e-pošte: vladimirh. horvat89@gmail.com. ORCID: https://orcid.org/0000-0002-4269-7470. 


\section{UVOD}

Suvremeni zatvorski sustavi predstavljaju balansiranu sinergiju državne prisile i konvencijama utvrđenih standarda ljudskih prava. Kroz povijest, zatvori su bili mjesta najgrublje torture, namjerne psihofizičke degradacije i dehumanizacije ljudi. Evolucija zatvorskih sustava izravna je posljedica promjena u društvu koje su stvarale pogodne uvjete za aplikaciju progresivnih ideja apriornog karaktera, a koje su humanističke probitke ponajviše ostvarile u dvadesetom stoljeću. Danas zatvorski sustavi, kako u svijetu, tako i u Nizozemskoj, predstavljaju izuzetno složen i delikatan sustav čija je svrha osigurati izvršenje kazne zatvora uz maksimalno poštovanje ljudskih prava, u sklopu individualnim potrebama prilagođenog programa, a sve u cilju resocijalizacije zatvorenika. Ta formula zatvorskog sustava nije se bitnije mijenjala u posljednjih pola stoljeća, no ono što se uvelike mijenjalo jest pristup u tumačenju, primjeni i provedbi iste. Prvi dio rada bavi se pitanjem rješavanja problema pretrpanosti zatvora, odnosno pitanjem zbog čega Nizozemska gasi zatvorske institucije, pri čemu je spoznaja o generatorima smjera i karaktera provedbe penitencijarne politike poslužila kao inicijalni otponac daljnjem istraživanju strukture i funkcioniranja suvremenog zatvorskog sustava u Nizozemskoj, opisanog u drugom dijelu rada.

\section{NIZOZEMSKI ZATVORSKI SUSTAV U KONTEKSTU PROMJENE SMJERA KAZNENE POLITIKE}

Kraljevina Nizozemska kao država oduvijek je predstavljala svojevrsni sinonim za toleranciju, široki spektar osobnih sloboda te izrazito otvoreno društvo. Unatoč općem uvjerenju kako je liberalna društvena klima pojava koja proizlazi iz perioda političkih previranja nakon pada Berlinskog zida, u Nizozemskoj je to dio povijesti i tradicije. ${ }^{1}$ Prema Tonry i Bijleveld, ${ }^{2}$ Nizozemska je omogućavala tiskanje knjiga mnogim disidentima kasnog srednjeg vijeka poput Spinoze, Erasmusa i Luthera, ali bila i utočiše za progonjene Sefarde (španjolske židove) te francuske hugenote. Elite (u pravilu liberalnih svjetonazora) imale su pragmatičan pristup u rješavanju problema uslijed zahtjeva ekonomskih i vjerskih kasti za efikasnošću i pravednošću države. Ta ista pragmatičnost očitovat će se u drugoj polovini dvadesetog stoljeća kroz primjere dekriminalizacije lakih opojnih droga, legalizacije eutanazije i istospolnih brakova, ali i zabrane privatnog posjedovanja naoružanja. ${ }^{3}$ Duboku podijeljenost društva po vjerskim i ekonomskim osnovama od unutarnjeg konflikta (koji su tada bili uobičajeni za europski kontinent) sačuvao je jedinstven pristup: osjetljiva pitanja rješavaju isključivi profesionalci, bez

1 Jedinstven primjer ukorijenjenosti tolerancije u Nizozemskoj nalazimo u pogovoru Đorđa Ignjatovića knjizi Granice patnje: “Čak i u vrijeme strahovitog progona vještica koji je na europskom Zapadu u kolektivnom ludilu koštao života više stotina tisuća nedužnih žena, u Nizozemskoj je pronađen originalan način da se to spriječi. U jednom malom mjestu kraj grada Gauda otvoren je centar u kome su sve osobe s teritorije Nizozemske mogla dobiti potvrdu da nisu bez težine (to je na sudovima Inkvizicije bio ključni dokaz da je neko vještica ili čarobnjak). O tome je izdavana potvrda koja je važila kako u mjestu vaganja, tako i drugdje." Christie, N., Granice patnje, Pravni fakultet Beograd, Edicija Svetska pravna baština, Beograd, 2015., str. 89.

2 Tonry, M., Bijleveld C., Crime, Criminal Justice, and Criminology in the Netherlands, 35. Crime\&Just. 1, 2007. Dostupno na: URL= http://scholarship.law.umn.edu/cgi/viewcontent.cgi?article=1505\&context=faculty-articles. 
upletanja politike. U prilog tome govori i činjenica kako su, primjerice, nakon osamostaljenja od Francuskog Carstva 1813. godine, zadržali Napoleonov kazneni zakonik (Code pénal), ali su isto tako izbacili porotu kao neprofesionalni element u procesu sudovanja. ${ }^{4}$ Nizozemski zatvori su među najstarijima u Europi; no jedino su oni prije 235 godina bojili ćelije dva puta na godinu, imali su zatvorske liječnike i kirurge te slutili ono što mi danas nazivamo rehabilitacijom. John Howard navodi kako eventualni posjetitelj ne bi mogao povjerovati da se nalazi u zatvoru, ${ }^{5}$ što jasno ukazuje na onodobne dosege njihova sustava. Povijest nas uči kako ekonomske, političke i socijalne promjene determiniraju razvoj društva, što se itekako odražava na uređenost zatvorskog sustava kao i položaj zatvorenika u istom. Problemi s rastućom zatvorskom populacijom s kraja dvadesetog stoljeća nisu zaobišli Nizozemsku. Primjer stabilnog, humanog i naprednog zatvorskog sustava, okarakteriziranog kao simbol nade penalne reforme ${ }^{6}$ sedamdesetih godina prošloga stoljeća, u samo tri desetljeća transformirao se u zatvorski sustav s izuzetno visokom stopom zatvorenika i naizgled nezaustavljivim tempom rasta. Negativni trend kulminirao je u 2006. godini, nakon čega dolazi do drastičnog pada broja zatvorenika. Zatvori su se postupno praznili, a broj zatvorenika 2014. godine pada ispod razine iz 1995. godine. ${ }^{7}$ Taj ponovni zaokret i izlazak nizozemskog zatvorskog sustava iz krize iznenadio je i vodeće eksperte na poljima kriminologije i penologije, ${ }^{8}$ što dovoljno govori o kompleksnosti cjelokupne teme. Ipak, moguće je govoriti o pojedinim uzrocima pozitivnih i negativnih trendova u razdobljima tijekom kojih prepoznajemo različite političke, ekonomske i društvene kontekste te njihove, barem okvirne refleksije na kaznenu politiku, a samim tim i na zatvorski sustav.

\subsection{PORATNI PREPOROD}

Prema Downes i Swaaningen, ${ }^{9}$ Nizozemska je u periodu nakon Drugog svjetskog rata doživjela ekonomski uzlet koji se odražavao u svim poljima društva, a ponajviše u socijalnoj komponenti. Blagostanje je pružalo zdrav oslonac progresivnim humanističkim idejama intelektualne elite, kojoj iskustvo zatvaranja i nepravde tijekom nacističke okupacije ostavlja dubok trag. Zamah liberalnog duha drastično redefinira zatvorski sustav kroz dokument Penitentiary Principles Act iz 1953. godine koji retribuciju zamjenjuje rehabilitacijom kao svrhom kazne zatvora. Također, enormnu ulogu u redefiniranju kaznene politike imala je asocijacija struč-

4 Tak, J. P. P., The Dutch Criminal Justice System: Organization and operation, Wetenschappelijk Onderzoek-en Documentatiecentrum (WODC), Den Haag, 1999., str. 5.

5 Howard, J., Stanje u zatvorima, Pravni fakultet Beograd, Edicija Svetska pravna baština, Beograd, 2015., str. 45.

6 Downes, D.; Swaaningen, R., The Road to Dystopia? Changes in the Penal Climate of Netherlands, Crime and Justice, Vol. 35, No. 1, Crime and Justice in the Netherlands, 2007., str. 31. Dostupno na: URL= http://www.jstor.org/stable/10.1086/650186.

7 Izvor: World Prison Brief: Netherlands. Dostupno na: URL= http://www.prisonstudies.org/country/netherlands.

8 Swaaningen i Downes su bili izrazito neoptimistični glede budućnosti nizozemskog zatvorskog sustava. Procesi koji su uslijedili nakon njihova analitičkog rada The Road to Dystopia? Changes in the Penal Climate of Netherlands iz 2007. godine teško su objašnjivi, zaključuje Swaaningen, tim više što je s početka 2000. godine političku vlast u Nizozemskoj preuzela izrazito desna opcija s predizbornim programom snažnijeg institucionalnog obračunavanja s kriminalom (obećana je politika pojačanog kažnjavanja, a ne rehabilitacije). Swaaningen, R., Reversing the Punitive Turn: The Case of the Netherlands, European Penology?, Hart Publishing, London, 2013., str. 339. Dostupno na: URL= http://dx.doi.org/10.5040/9781474200059.ch-015. 
njaka pod imenom Utrecht School, čiji su članovi bili ugledni odvjetnici, psihijatri, psiholozi i kriminolozi. Ivičević Karas ${ }^{10}$ navodi kako u tom periodu na prostoru čitavog europskog kontinenta dolazi do zamaha ideje rehabilitacije zatvorenika i humanizacije zatvorske kazne, i to djelovanjem od strane francuskog pokreta Nove društvene obrane (Défense sociale nouvelle). U tom periodu Nizozemska postaje europski dragulj tolerancije, generator liberalnih ideja i progresivnih pokreta. Ekonomski razvitak omogućio je socijalnu stabilnost i blagostanje, što je otvorilo prostor svojevrsnim penološkim eksperimentima u vidu proučavanja zatvorenika kao individue koja se može vratiti na pravi, društveno prihvatljiv put, uz primjenu kvalitetnih i odgovarajućih mjera. Averzija eksperata spram institucionaliziranja većine slučajeva prijestupnika kao rehabilitacijski kontraproduktivnom obliku kažnjavanja, stvorila je klimu iznimno redukcionističke kaznene politike uz široku primjenu oprosta, uvjetnih kazni, ranijeg otpusta i nepoduzimanja kaznenog progona za manja kaznena djela, što je rezultiralo najnižom stopom zatvorenika u Europi u periodu od 1950. do polovine 1980. godine.

\subsection{DVA DESETLJEĆA KRIZE: 1985.-2006.}

Ono što je tiho ali nezaustavljivo pratilo ekonomski i društveni napredak Nizozemske u poratnom periodu, a što će kasnije determinirati političke i socijalne promjene, možemo uvidjeti u sljedećim procesima. Porast imigrantske populacije $\mathrm{e}^{11}$ ozbiljno je mijenjao ekonomsku, a potom i socijalnu sliku koja je ionako bila pod tihim udarom naftne krize iz sedamdesetih godina. Getoizacija imigranata u gradovima, kao i afirmacija novih generacija autohtonih Nizozemaca odraslih u izobilju i bez iskustva užasa Drugog svjetskog rata, postupno transformiraju kulturne aspekte društva. Masovni turizam i otvaranje granica generirali su stalno povećanje protoka narkotika, a samim tim i involviranje većeg broja ljudi u kriminalne djelatnosti, kako stranaca tako i domaćih državljana. Navedeni procesi utjecali su na sveopći rast kriminaliteta koji je, pokazat će se, imao korozivni učinak na društvo ponajprije kroz osjećaj sigurnosti i povjerenja u pravosudni sustav.

Tablica 1.

\begin{tabular}{|c|c|c|}
\hline Godina & Ukupan broj zatvorenika & $\begin{array}{c}\text { Stopa zatvoreničke populacije } \\
\text { (na 100.000 stanovnika) }\end{array}$ \\
\hline 1980. & 3.873 & 27 \\
\hline 1985. & 4.888 & 34 \\
\hline 1990. & 6.662 & 45 \\
\hline 1995. & 11.886 & 77 \\
\hline 2000. & 13.847 & 87 \\
\hline 2006. & 20.463 & 125 \\
\hline
\end{tabular}

10 Autorica uočava kako je stavljanje imperativa na rehabilitacijski tretman zatvorenika i daljnju humanizaciju kazne zatvora otvorilo prostor i razvoju penitencijarnog prava. Ivičević Karas, E., Penitencijarno pravo, Narodne novine, Zagreb, 2016., str. 13.

11 Tri su glavne podjele imigrantske populacije u Nizozemskoj: radnici pozvani od nizozemske Vlade šezdesetih godina zbog nedostatka radne snage (Južna Europa, Turska i Maroko); imigranti iz bivših nizozemskih kolonija današnje Indonezije, Surinama i Antila, a koji migriraju u poratnom razdoblju; azilanti iz Afganistana, Iraka i Somalije, čiji priljev počinje osamdesetih godina prošloga stoljeća. Od 16 milijuna stanovnika koliko ima Nizozemska, tri milijuna stranog su podrijetla. Vidi: Multicultureel Nederland: History of immigration in the Netherlands, University College London. Dostupno na: URL= http://www.ucl.ac.uk/ dutchstudies/an/SP-LINKS-UCL-POPUP/SPs-english/multicultureel-gev-ENG/pages/geschiedenis-imm.html. 
Tablica $1 .^{12}$ jasno pokazuje u kojoj mjeri se nizozemski zatvorski sustav transformirao u samo 25 godina, što je neposredan rezultat zaokreta u kaznenoj politici. Downes i Swaaningen $^{13}$ smatraju kako je odlučujući razlog promjene kaznene politike u Nizozemskoj upravo drastičan rast kriminala s početka osamdesetih godina. Nije tajna zbog kojih razloga političke struje potenciraju obračun s kriminalitetom u svojim populističkim programima, pogotovo ako znamo koliko je javnost osjetljiva na sigurnost svojih ulica. Nova politička klima više nije mogla izdašnom socijalnom politikom nadomjestiti negativni efekt porasta kriminala te se okretala mjerama u skladu sa zahtjevom javnosti - snažnijim kaznama i zatvorima. Tak ${ }^{14}$ objašnjava doprinos politike oštrijih zatvorskih kazni rastu broja zatvorenika, navodeći činjenicu kako se od 1970. godine do polovice devedesetih broj kazni zatvora udvostručio, a broj ukupnih presuđenih godina zatvorskih kazni uvećan je čak pet puta. Nadalje, on smatra kako je veliku ulogu u rastu broja zatvorenika odigralo oslanjanje na listu čekanja (waiting list). Naime, krajem sedamdesetih, prijestupnici koji nisu prethodno bili u istražnom zatvoru (pritvoru), a koji su osuđeni na kaznu zatvora, zbog popunjenosti zatvorskog kapaciteta bili bi pušteni na slobodu uz obvezu odsluženja kazne nakon što se kapaciteti oslobode, a kada bi se čekanje odužilo izvan razumnih rokova kazna bi bila oproštena. To je zapravo stvorilo jedno institucionalno začepljenje zbog konstantnog priljeva zatvorenika, ali i sve jači pritisak javnosti zbog činjenice kako prijestupnici nisu zatvoreni, a trebali bi biti. ${ }^{15}$ Odgovor vlasti na problematičnu situaciju ogledao se u vidu širenja zatvorskih kapaciteta u periodu osamdesetih te izgradnji 14 novih zatvora u periodu devedesetih. ${ }^{16}$ Stopa rasta zatvorenika je galopirala, a pretrpanost je stalno prijetila sustavu. Van Ruller i Beijers, ${ }^{17}$ analizirajući stope zatvaranja u Nizozemskoj dodatno pojašnjavaju razloge negativnih trendova kroz porast broja teških kaznenih djela te oštriju zakonsku regulativu u vezi s teškim drogama. Nadalje, kao razlog navode i nastalu potrebu za pojačanim zatvaranjem osumnjičenika zbog otvorenije tranzitne politike i opasnosti od izbjegavanja pravde jednostavnim napuštanjem države. Drastični porast broja zatvorenika u razdoblju od 2000. do 2006. godine u velikoj mjeri generiran je i politikom široke primjene

12 Izvor: World Prison Brief: Netherlands. Dostupno na: URL= http://www.prisonstudies.org/country/netherlands.

13 Downes; Swaaningen, op. cit. (bilj. 6), str. 43.

14 Tak, op. cit. (bilj. 4), str. 2.-3. Navedeni primjer ujedno objašnjava odnos intenziteta kriminaliteta i intenziteta zatvaranja. Naime, devedesetih godina prošloga stoljeća kriminal se stabilizirao, ali su stope zatvorenika nastavile rasti, što znači da kriminalitet utječe na popunjenost zatvora samo u mjeri u kojoj kaznena politika države to dopušta. Ne treba zanemariti ni činjenicu duljih zatvorskih kazni koje prolongiraju zadržavanje zatvorenika u ustanovi, što ima negativni utjecaj na tempo pražnjenja kapaciteta. U skladu s navedenim možemo slobodno konstatirati kako rast stope zatvorenika nije pouzdani indikator, niti ekvivalent rastu stope kriminaliteta. No, pitanje koje se rijetko postavlja, pogotovo u državama izrazito punitivne politike poput SAD-a, jest u kojoj mjeri stanje zatvorske krize prekapacitiranosti posredno utječe na porast stope kriminala; problem pretrpanih zatvora u takvoj razvijenoj državi stabilne ekonomije nije adresiran na aspekt pravosuđa, nego na infrastrukturna ulaganja kojima se otvaraju kapaciteti za dodatni rast broja zatvorenika. Kontakt sa zatvorom ostvaruje sve veći broj stanovnika, što može identitetski preoblikovati čitave generacije; zatvor postaje učestala pojava, "poslovni rizik", pa čak i dio subkulture, a ne (među ostalim) sredstvo zastrašivanja; kontakt s (najčešće sitnim) kriminalom, koji je možda bio stvar mladenačke eskapade ili jedini način trenutačnog namirenja elementarnih potreba postaje glavni izvor prihoda i trajno zanimanje nakon iskustva pretrpanih zatvora bez sredstava, mogućnosti i kapaciteta provedbe bilo kakvog kvalitetnog rehabilitacijskog programa, što samo pospješuje postpenalnu stigmatizaciju.

15 Tak navodi jedan fascinantan podatak nizozemskog Državnog ureda za reviziju (State Audit Comittee) iz 1996. u kojem se govori o više od 20.000 izrečenih zatvorskih kazni koje čekaju na izvršenje zbog nedostatka kapaciteta. Tak, op. cit. (bilj. 4), str. 2.

16 Svi novoizgrađeni zatvori bili su zatvorenog tipa; poluotvoreni i otvoreni tipovi zatvora nisu bili izgrađeni te su kao takvi činili nešto više od 8\% svih nizozemskih zatvorskih ustanova. Beijerse, J.; Swaaningen, R., Non-custodial sanctions, u: Dutch prisons (ur. Boone, M., Moerings, M.), BJu Legal Publishers, Den Haag, 2007., str. 88.

17 Ruller, S., Beijers, G., De gevangenisstatistiek in het licht van de geschiedenis (Prison statistics in historical perspective), Justitiile Verkenningen (1995). 21:35-52. Citirano prema: Tonry, Bijleveld, op. cit. (bilj. 2), str. 16. 
mjere istražnog zatvora radi suzbijanja krijumčarenja narkotika ingestijom (tzv. narkomule) te pritvaranjem (umjesto dotadašnjim automatskim protjerivanjem) ilegalaca u centre za deportaciju, ${ }^{18}$ koji su najčešće jednakih ili gorih uvjeta od samih zatvora. Nadalje, promjena gledišta sudačke empatije s počinitelja na žrtvu kaznenog djela te trendovi oštrije kaznene opresije okolnih zemalja koji su u kombinaciji s kritikama nizozemske javnosti i senzacionalističkim medijima dodatno vršili pritisak na odluke sudbenih tijela, također predstavljaju bitan dio mozaika ove zatvorske krize.

Navedena mišljenja stručnjaka razjašnjavaju procese koji su rezultirali zatvorskom krizom. Velika većina država svijeta iskusila je slične ili teže negativne trendove, zbog gotovo istih razloga. Ono što Nizozemska nije iskusila, a što predstavlja glavni penitencijarni problem SAD-a, Italije, Francuske, Velike Britanije, kao i drugih država, odnosi se na prekapacitiranost zatvora u mjeri u kojoj ta institucija gubi mogućnost kvalitetne provedbe penitencijarnih programa te se kazna zatvora svodi na puko zadržavanje velikog broja ljudi u nehumanim uvjetima, bez perspektive ulaganja u nove programe i obrazovanja osoblja zbog preopterećenih proračuna. ${ }^{19}$ Takvim populističkim pristupom problem se samo širio, skupi zatvori su se gradili i popunjavali, a rješenje za problem nije se naziralo. Nizozemsku, unatoč promjeni kaznene politike, nisu olako napustile tekovine postratnih principa rehabilitacije i penalnog redukcionizma. ${ }^{20}$ Downes i Swaaningen ${ }^{21}$ navode kako su pojedini eksperti na polju penologije i penitencijarnog prava ustrajno pružali otpor transformaciji zatvorskog sustava koja je bila u punom zamahu osamdesetih godina u svijetu. Njihova upornost u zalaganju za redukcionistički pristup svakako je spriječila snažniju eskalaciju rasta stope zatvaranja, pokazat će se, barem za dogledno vrijeme, jer krajem devedesetih nizozemski zatvori prolaze kroz razdoblje najveće stope zatvaranja u samo pola desetljeća ${ }^{22}$ unatoč činjenici stagnacije stope kriminaliteta devedesetih godina prošloga stoljeća te laganog pada iste od 2002. godine. ${ }^{23}$ Protutežu prijetećoj prekapacitiranosti zatvora pravosudni sustav kompenzirao je kroz široku aplikaciju alternativa zatvorskim kaznama. Novčane globe i rad za opće dobro postale su preferirane sankcije, a državni odvjetnici široko su koristili diskrecijske ovlasti u cilju tzv. diverzije (diversion), odnosno maksimalnog rasterećivanja sudova od kaznenih postupaka za većinu kaznenih djela. Tablica $2 .{ }^{24}$ svjedoči o ulozi javnog

18 Beijerse, Swaaningen, op. cit. (bilj. 16), str. 88.

19 Razmjere navedenog problema u SAD-u objašnjava Coyle: "Posljedice ogromnog povećanja broja zatvorenika u pritvorima i zatvorima osjećaju se na svim razinama, a odgovori zatvorskih uprava na ovu pojavu bile su raznolike. U nekim slučajevima, kao i u mnogim drugim zemljama, zatvori su jednostavno postali pretrpani i neminovno je došlo do poteškoća u vezi s prostorom, kuhanjem, higijenom i medicinskom njegom, kao i do povećanja nasilja (Chesney-Lind, 1998.). Postalo je uobičajeno da se zatvorenici smještaju u sportsku salu i edukacijske jedinice (Monterey County, 2000.). U nekim dijelovima zemlje, vlasti su morali uvesti šatore za smještaj zatvorenika (US Department of Justice, 1997.)." Coyle, Upravljanje zatvorima u vremenu promjena, International Centre for Prison Studies, London, 2002., str. 33.

Rutherford opisuje penalni redukcionizam kao teorijsku skepsu spram eventualnih pozitivnih učinaka zatvaranja, kao i nultu toleranciju sustava prema stanju prekapacitiranosti zatvora te načelno odbijanje ideje širenja zatvorskih kapaciteta. Redukcionizam se ostvaruje dekriminalizacijom, sužavanjem zakonske mogućnosti izricanja kazne zatvora i istražnog zatvora (pritvora) te širokom primjenom nezatvorskih mjera i kazni (tzv. Front door strategija); zatvorske kazne moraju biti što kraće, uz prakticiranje ranijeg otpusta kad god je moguće (tzv. Back door strategija). Rutherford, A., Prisons and the Process of Justice: The Reductionist Challenge (Heinemann, London, 1984.). Citirano prema: Snacken, S., Zyl Smit, D., Principles of European Prison Law and Policy: Penology and Human Rights, Oxford University Press, New York, 2009., str. 87. Vidi: Tablica 1.

23 Swaaningen, op.cit. (bilj. 8), str. 346. 
tužitelja u rješavanju kaznenih predmeta, i to u visini gotovo polovice ukupnog broja, ali i o širokoj primjeni alternativnih sankcija od strane suda u 1995. godini.

\section{Tablica 2.}

\begin{tabular}{|c|c|}
\hline $\begin{array}{l}\text { Javno tužiteljstvo - od } 260.000 \text { zaprimljenih predmeta od strane } \\
\text { policije, } 126.000 \text { predmeta rješava na sljedeći način: }\end{array}$ & $\begin{array}{l}\text { Sud - u } 130.500 \text { presuda, odluke su } \\
\text { sljedeće: }\end{array}$ \\
\hline odbačaj kaznene prijave: 30.000 & novčana kazna: 47.000 \\
\hline odbačaj kaznene prijave prema načelu svrhovitosti: 30.000 & rad za opće dobro: 15.000 \\
\hline transakcija: ${ }^{25} 62.000$ & kazna zatvora: 47.000 \\
\hline ostalo: 4.000 & ostalo: 21.500 \\
\hline
\end{tabular}

\subsection{PREVLADAVANJE KRIZE}

Nizozemski zatvori od 2006. godine ulaze u etapu opadanja zatvorske populacije što je dovelo do postupnog gašenja određenog broja zatvorskih institucija tijekom idućega desetljeća zbog nedovoljne popunjenosti (Tablica 3.) ${ }^{26}$.

\section{Tablica 3.}

\begin{tabular}{|l|c|c|c|c|c|c|c|c|}
\hline Godina & 2000. & 2002. & 2004. & 2006. & 2008. & 2010. & 2012. & 2014. \\
\hline Stopa zatvorenika (na 100.000 stanovnika) & 87 & 100 & 123 & 125 & 100 & 92 & 82 & 69 \\
\hline
\end{tabular}

Kriminalitet u Nizozemskoj u prvom desetljeću 21. stoljeća, uz manje oscilacije, ulazi u fazu drastičnog pada. De Waard ${ }^{27}$ objašnjava kako su na to utjecali faktori poput unaprjeđenja sustava sigurnosti na domaćoj i međunarodnoj razini, demografskih promjena, slabljenja prometa heroinom, snažne i stimulirajuće uloge centralnih vlasti te osnaženja kapaciteta i autoriteta pravosudnih tijela. Ideju o padu stope zatvaranja zbog pada stope kriminaliteta Swaaningen ${ }^{28}$ pobija, navodeći kako je kriminalitet pao u većini država zapadne Europe, dok se stope zatvaranja nisu bitnije mijenjale, odnosno ostale su na visokoj razini. Objašnjenje nizozemskog fenomena pada zatvorske stope Swaaningen tumači kroz drastično smanjenje izricanja bezuvjetnih kazni zatvora od strane suda, kao i smanjenu uporabu istražnog zatvora

25 Transakcija predstavlja specifičnu formu nagodbe s javnim tužiteljem u vidu uplate novčanih sredstava u državni proračun. Iako postoji od 1838., puni zamah njezine implementacije započinje 1983. godine (Financial Penalties Act) kada joj se proširuje mogućnost izricanja i na kaznena djela zapriječene kazne do šest godina zatvora. Minimalan iznos je tri eura, a maksimalni ne smije biti veći od zakonom propisane novčane kazne. Transakciju mogu pratiti određeni uvjeti poput oduzimanja pribavljene imovinske koristi protupravnom radnjom, oduzimanja materijalnih dobara koji su predmet krivotvorenja, djelomična ili potpuna naknada štete nastale kaznenim djelom. Odbijanje transakcije po automatizmu inicira sudski proces, upravo zbog toga je ovaj institut i kritiziran kao varijacija američkog sustava nagodbe (plea-bargaining) zbog umanjivanja prava optuženika, kao i zbog mogućeg favoriziranja određenih socijalnih skupina. Tak, J. P. P., The Dutch Criminal Justice System, Wolf Legal Publishers, Nijmegen, 2008., str. 87.-88.

26 Izvor: World Prison Brief: Netherlands. Dostupno na: URL=http://www.prisonstudies.org/country/netherlands.

27 Waard, J., Explaining the crime dropin The Netherlands: Theimportance of comparisons withotherindustrialised countries, 2015. Dostupno na: URL=https://www.researchgate.net/profile/Jaap-De-Waard/publication/287759866-The-crime-drop-in-The-Netherlands-andother-industrialized-countries-Trends-and-possible-explanations/links/567 922db08aeaf87ed8afad6.pdf?origin=publicationdetail. 
u odnosu na 2000. godinu te generalno slabljenje atmosfere straha u javnosti u vezi s kriminalom. ${ }^{29}$ Proceduralne izmjene ovlasti državnog odvjetnika iz 2005. godine uvele su institut izvansudske nagodbe državnog tužitelja i prijestupnika (ograničenu na nezatvorske sankci$\mathrm{je}^{30}$ ) koja će dodatno doprinijeti rasterećivanju sudova i općenito smanjenju zatvorske populacije. Antiimigrantska politika također je ublažena. U 2007. godini 27.000 imigranata (koji bi inače bili smješteni u imigrantske centre) dobilo je oprost. Swaaningen zaključuje kako se ne treba zavaravati s parametrima. Nizozemska nije postala manje punitivna, niti je na tragu povratka u doba progresivnih ideja sedamdesetih godina prošloga stoljeća, nego je samo pronašla načine jačanja socijalnih kategorija u borbi protiv nesigurnosti i društvenih smetnji, ${ }^{31} \mathrm{i} u$ potpunosti je u pravu. Društvene promjene koje su uzdrmale Nizozemsku osamdesetih godina 20. stoljeća redefinirale su prioritete političkih struktura. Interesi koji su stajali u pozadini mehanizma rješavanja problema prijeteće prenapučenosti u potpunosti su izašli na vidjelo nakon rješavanja opisane krize. Rentabilnost sustava i sigurnost društva čine osovinu na koju se oslanja nova kaznena i penitencijarna politika Nizozemske. Boone ${ }^{32}$ uočava štetne učinke promjene kaznene politike analizirajući aspekt pooštrene regulative glede kaznene evidencije, koji predstavlja minoran primjer osnaženja načela sigurnosti u odnosu na privatnost. ${ }^{33}$ Plan ministarstva pravosuđa (Masterplan DJI 2013-2018) glede zatvorskih ustanova ide u istom pravcu. Uz drastične rezove i zatvaranje polupraznih institucija, najavljuju se i ukidanja reintegracijskih programa, privremenog otpusta te vikenda i večernjih programa, a sve radi smanjenja izuzetno visokih troškova zatvorskog sustava. ${ }^{34}$

29 Odnosno, možemo govoriti o porastu tolerancije društva na kriminalitet, što implicira slabiji pritisak javnosti na politiku zatvaranja i pravosuđe. Optužbe za "meku" kaznenu politiku predstavljaju opasno sredstvo manipuliranja koje se u političke svrhe zloupotrebljavalo ponajviše osamdesetih i devedesetih godina prošloga stoljeća.

Sporazum se može odnositi na novčane kazne, plaćanje kompenzacije žrtvi (naknada štete, bolnina), rad za opće dobro (do 180 sati) te isključenje iz prometa (na maksimalno šest mjeseci).

31 Pesimistični ton Swaaningena predstavlja dijametralnu suprotnost od razmišljanja njegovih kolega iz država oštrih kaznenih politika i visoke stope zatvaranja. Dok su potonji pomalo zavedeni rezultatima nizozemske kaznene politike i općenito funkcioniranjem sustava, Swaaningen priznaje kvalitetu zatvorskog života i nisku stopu inkapacitiranosti, ali kao abolicionist neumorno inzistira na jačim rehabilitacijskim mjerama i maksimalnoj restrikciji uporabe zatvora u Nizozemskoj. Detaljnije v. O'connor, R., The United States Prison System: A Comparative Analysis, Graduate Theses and Dissertations, University of South Florida, 2014. Dostupno na: URL= http://scholarcommons.usf.edu/cgi/ viewcontent.cgi?article=6282\&context=etd., kao i: Subramanian,R., Shames, A., Sentencing and Prison Practices in Germany and the Netherlands: Implications for the United States, Vera Institute of Justice, New York, 2013. Dostupno na: URL= http://archive.vera.org/sites/default/files/resources/downloads/ european-american-prison-report-v3.pdf., te: Swaaningen, op. cit. (bilj. 8).

32 Boone, M., Judicial Rehabilitation in the Netherlands: Balancing between safety and privacy, European Journal of Probation, University of Bucharest, Vol. 3, No. 1, 2011, pp, 63-78, ISSN: 2006 - 2203., p. 65. Dostupno na: URL=http://www.ejprob.ro/ index.pl/judicial-rehabilitation-in-the-netherlands-balancing-between-safety-and-privacy.

33 U kontekstu kaznene evidencije prevalencija sigurnosti znači kako vokacijska rehabilitacija kao dobar motiv i temelj procesa potpune resocijalizacije pada u drugi plan i više nije u fokusu sistema.

34 Sentences and non-punitive orders: custodial sentences. Dostupno na: URL=https://www.government.nl/ topics/sentencesand-non-punitive-orders/contents/custodial-sentences. 


\section{SUVREMENI ZATVORSKI SUSTAV U NIZOZEMSKOJ}

Imajući u vidu kvalitetu života zatvorenika, ${ }^{35}$ kvalitetu provedbe ponuđenih programa te općenito funkcioniranje cjelokupnog sustava, slobodno možemo reći kako je suvremeni zatvorski sustav u Nizozemskoj jedan od najkvalitetnijih u Europi, a samim tim i u svijetu. Rasterećenje zatvorskih kapaciteta otvorilo je prostor kontinuiranom razvoju kvalitete pristupa zatvorenicima i snažnijoj modernizaciji cjelokupnog sustava. Zaštita temeljnih ljudskih prava zatvorenika, uz opsežnu nacionalnu legislativu, zajamčena je i međunarodnim dokumentima. Među najvažnije usvojene dokumente spadaju Konvencija o građanskim i političkim pravima, Europska konvencija o ljudskim pravima i temeljnim slobodama te Europska zatvorska pravila. ${ }^{36}$ Prema Laffineur, ${ }^{37}$ Nizozemska je od 1959. godine imala 141 presudu Europskog suda za ljudska prava u pitanjima povrede ljudskih prava zatvorenika, čime spada u krug država s najmanjim brojem presuda, a Odbor za pravne poslove i ljudska prava na Konferenciji u studenome 2010. godine u Skoplju istaknuo je Nizozemsku u kontekstu pozitivne suradnje sa Sudom. Promptno djelovanje u povodu nekih od najvažnijih slučajeva pred Europskim sudom za ljudska prava, a koji su se odnosili na ekscesivnu primjenu preventivnih mjera, odnosno pretrage zatvorenika (Van der Ven $v$. The Netherlands, ${ }^{38}$ Lorse and Others $v$. The Netherlands) ${ }^{39}$ i neljudskih uvjeta zatvora autonomne teritorije Aruba na Karibima (Mathew v. The Netherlands), ${ }^{40}$ predstavljaju primjer uvažavanja prakse i primjene odluka Suda. ${ }^{41}$

\subsection{ORGANIZACIJA}

Cjelokupan zatvorski sustav u Nizozemskoj pod izravnom je kontrolom Nacionalne agencije za kazneno-popravne institucije (Dienst Justitiele Inrichtingen) ${ }^{42}$ koja se nalazi u sastavu

35 Zaštita ljudskih prava predstavlja jedan od prioriteta u nizozemskim zatvorima, a posebnom napretku posljednjih godina svjedoči i izvješće Europskog odbora za sprječavanje mučenja i nečovječnog ili ponižavajućeg postupanja ili kažnjavanja, u kojem su pozitivno ocijenjeni stanje i opremljenost zatvorskih zgrada i ćelija, osnovni zatvorski režimi ali i rješavanje problematičnih situacija poput nasilja u pojedinim zatvorima. Preporuke se odnose na jačanje uloge medicinskih radnika, unaprjeđenje obrazovnih programa, pružanja mogućnosti samostalne pripreme hrane u svim zatvorima itd. Report to the Government of the Netherlands on the visit to the Netherlands carried out by the European Committee for the Prevention of Torture and Inhuman or Degrading Treatment or Punishment (CPT) from 2 to 13 May 2016., CPT/Inf (2017) 1, Strasbourg, January 2017, str. 23. Dostupno na: URL= https:// rm.coe.int/16806ebb7c.

36 Laffineur, J., Workstream 2 - National Reports - The Netherlands, CRID\&P Universite de Louvain, Belgique, str. 11. Dostupno na: URL= http://www.prisonlitigationnetwork.eu/wp-content/uploads/2016/11/country-report-netherlands.pdf.

37 Ibidem, str. 2.

38 ECHR, 4. February 2003., Van der Ven v. The Netherlands, Application no. 50901/99. dostupno na: URL= http:// hudoc.echr.coe. int/eng?i=001-6002.

39 ECHR, 27. January 2004., Lorse and Others v. The Netherlands, Application no. 44484/98. Dostupno na: URL= http://hudoc.echr. coe.int/eng?i=001-23725.

40 ECHR, 29. September 2005., Mathew v. The Netherlands, Application no. 24919/03. Dostupno na: URL= http://echr.ketse.com/ doc/24919.03-en-20050929/view/.

41 Novčane satisfakcije, ukidanje ekscesivnih kontrolnih mjera, modificiranje postojećih pravila postupanja prema zatvorenicima, renoviranje i adaptacija životnog prostora zatvorenika samo su neke od mjera koje su uslijedile nakon izrečenih presuda. Laffineur, op. cit. (bilj. 36), str. 8. 
Ministarstva pravosuđa. Glavni ured, na čijem čelu je glavni ravnatelj, nalazi se u Den Haagu, a snosi odgovornost izvršenja zatvorskih kazni u skladu sa zakonom, kao i odgovornost za sve vrste poslova zatvorskih ustanova. Diversifikacija Agencije ostvarena je kroz tri sektora poslova:

1. Sektor zatvorske administracije i smještaja imigranata

2. Sektor psihijatrijske njege i popravnih ustanova za maloljetnike

3. Sektor individualnih poslova (dijagnostike).

Prateće nacionalne službe unutar Agencije definirane su kroz pitanja transporta i usluga, dušobrižništva, obuke zaposlenika, upravljanja financijama i informatičkim sektorom, kontrole sigurnosti i integriteta zaposlenika, psihijatrijske analitike, istraživanja i savjetodavnih aktivnosti. $^{43}$

Agencija nadzire rad i funkcioniranje institucija sljedećih kategorija:

1. zatvori - služe izvršenju mjere istražnog zatvora te izvršenju kratkotrajnih zatvorskih kazni

2. kaznionice - služe izvršenju zatvorske kazne punoljetnih zatvorenika

3. kazneno-popravne institucije za maloljetnike - služe provedbi korekcijskih mjera nad prijestupnicima uzrasta od 12 do 18 godina

4. zatvorske bolnice - služe psihijatrijskom liječenju punoljetnih zatvorenika zbog mentalnih bolesti i ovisnosti

5. centri za prihvat stranaca - služe smještaju stranaca ilegalnog boravka ili odbijenog ulaska u državu, odnosno zatvaranju krijumčara narkotika. ${ }^{44}$

Agencija funkcionira kroz aktivnu suradnju s javnim tužiteljstvom i sudovima, odborom za prava i zaštitu djece, službom za prihvat i repatrijaciju imigranata, nacionalnom zdravstvenom organizacijom, probacijskom službom te lokalnom i regionalnom samoupravom. ${ }^{45}$ Strateški ciljevi sustava zatvorske politike kreirani su od strane Ministarstva pravosuđa, a Agencija i zatvorski upravitelji imaju slobodu kreiranja načina ostvarivanja tih ciljeva kroz samostalno upravljanje materijalnim, financijskim i kadrovskim resursima. Institucionalna decentralizacija ove vrste rezultat je temeljitih reformi zatvorskog sustava devedesetih godina prošloga stoljeća. Agencija godišnje raspolaže s 2,3 milijarde eura proračunskih sredstava.

\subsection{ZATVORSKE (PENITENCIJARNE) INSTITUCIJE}

Nizozemska je u 2013. godini imala pod nadzorom agencije 77 institucija, od toga 51 zatvorsku i devet kazneno-popravnih institucija, četiri centra za prihvat te 13 zatvorskih bolni-

43 Službena stranica Ministarstva pravosuđa Kraljevine Nizozemske. Dostupno na: URL=https://www.dji.nl/ english/organisation/ index.aspx.

44 This is the Custodial Institutions Agency (DJI), Den Haag, June, 2015. Službena stranica Ministarstva pravosuđa Kraljevine Nizozemske. URL= https://www.dji.nl/binaries/lr-93324-ditisdji-en-v2-3-tcm41-121757.pdf.

45 Custodial Institutions Agency, Den Haag, May, 2009. Službena stranica Ministarstva pravosuđa Kraljevine Nizozemske. URL= https://www.rijksoverheid.nl/documenten/brochures/2010/09/30/custodial-institutions-agency. 
ca. Unatrag nekoliko godina zatvoreno je 19 zatvorskih institucija, no u 2016. godini otvoren je najveći i najmoderniji nizozemski zatvor Judicial Complex Zaanstad kapaciteta 1000 mjesta. Uz kaznionicu, institucija posjeduje integrirana krila psihijatrijskog centra i zatvora. Zatvori poluotvorenog tipa kapaciteta su uglavnom do 100 mjesta, dok one otvorenog tipa ne prelaze 50 mjesta radi lakše kontrole i suradnje s lokalnim zajednicama i stanovništvom. Prosječno zadržavanje u institucijama te troškovi smještaja detaljnije su prikazani u Tablici $4 .{ }^{46}$ Ista nam jasno ukazuje na tendenciju minimalnog zadržavanja najvećeg broja zatvorenika unutar kaznionica, čime se institucije maksimalno rasterećuju. Treba napomenuti kako kazneno-popravne institucije za maloljetnike, centri za prihvat i zatvorske bolnice ne spadaju u penitencijarne institucije.

\section{Tablica 4.}

\begin{tabular}{|l|l|l|}
\hline Skupina & Prosječno zadržavanje u institucijama & $\begin{array}{l}\text { Dnevni trošak smještaja } \\
\text { po jednoj osobi }\end{array}$ \\
\hline $\begin{array}{l}\text { Punoljetni } \\
\text { zatvorenici }\end{array}$ & $\begin{array}{l}\text { 97 dana }(59 \% \text { do mjesec dana; 15\% do jedne godine; 6\% dulje od jedne } \\
\text { godine; 33 zatvorenika služe doživotnu kaznu zatvora) }\end{array}$ & $\begin{array}{l}245 \text { eura } \\
439 \text { eura (odjeli za njegu) }\end{array}$ \\
\hline Maloljetnici & 5,5 mjeseci & 607 eura \\
\hline Pacijenti & 7,5 godina & 508 eura \\
\hline Imigranti & 55 dana & 211 eura \\
\hline
\end{tabular}

Zatvorski upravitelji prolaze kroz temeljite obuke Ministarstva pravosuđa u kojima se educiraju o pitanjima kvalitetnog upravljanja, planiranja i transformacije sustava, čime se jača svijest o međusobnoj ovisnosti institucija i važnosti liderstva. Upravitelji ne smiju biti pasivni nalogodavci, oni moraju stalno raditi na unaprjeđenju sustava. Uz kvalitetu uprave, traži se i motiviranost osoblja pa pitanja motivacije i inspiracije zaposlenika čine sastavni dio edukacije. Unatoč modernim menadžerskim pristupima u upravljanju zatvorima, savjetodavni kadar čine eksperti koji razumiju struku, pitanja načela i temeljnih vrijednosti. ${ }^{47}$ Reforme u Nizozemskoj glede transparentnosti javne uprave i usmjeravanje na učinkovitost izravno su utjecale i na zatvorski sustav. Zatvorski službenici ohrabrivani su u percepciji jednakosti s ostalim djelatnicima vladinog, kao i civilnog sektora. Time je osoblju pojačana svijest o važnosti njihove djelatnosti, što je imalo pozitivne učinke na njihovu učinkovitost. ${ }^{48}$

Zatvorska pravila (Penitentiary Principles Act, Penitentiaire beginselenwet) iz $1998 .{ }^{49}$ godine predstavljaju temeljni dokument izvršavanja kazne zatvora. Osnovna načela izvršenja kazne

46 Izvor: This is the Custodial Institutions Agency (DJI), op. cit. (bilj. 44), str. 12., 17.

47 Ovdje nalazimo pozitivne strane zatvorskog sustava u Nizozemskoj. Naime, neupitna je kvaliteta odnosa prema zatvorenicima, kao i uvjeta u kojima se odvija proces izdržavanja zatvorske kazne. Slobodno bi se moglo reći kako zatvorenici u Nizozemskoj imaju bolji životni standard od velikog dijela slobodnog stanovništva u svijetu. Zatvorska kazna trebala bi podrazumijevati oduzimanje slobode, ali ne i elementarnog životnog standarda. Imperativ humanizacije kazne zatvora predstavlja povijesni princip nizozemske penitencijarne filozofije.

48 Coyle, op. cit. (bilj. 19), str. 70. Važnost izobrazbe dolazi do izražaja još i više ako uzmemo u obzir kako posao zatvorskog čuvara, nažalost, nije u društvenoj hijerarhiji cijenjeno zanimanje niti upravne strukture prioritiziraju ovu djelatnost. Osobe koje se zapošljavaju u zatvorskom sustavu, ponajprije kao čuvari, u pravilu ne vladaju poljima psihologije i sociologije, niti su ovladali komunikacijskim vještinama potrebnim za verbalno rješavanje situacija povećanog stresa i preventivne, ad hoc analize, procjene i prognoze zatvoreničkog ponašanja. Stoga, adekvatna i kontinuirana izobrazba osoblja predstavlja okosnicu kvalitetnog provođenja rehabilitacijskog programa, ali i sveopće sigurnosti unutar zidova penitencijarne institucije.

49 Usvojena 18. srpnja 1998. godine od strane nizozemskog parlamenta, prijevod i izvornik dostupni na: URL= http://www.ilo.org/ dyn/natlex/natlex4.detail?p-lang=en\&p-isn=71628. 
zatvora odnose se na rehabilitaciju,$^{50}$ hitnost izvršenja sankcije te minimalizaciju nametanja ograničenja zatvoreničkoj populaciji. Svojim pravilima propis definira prava i obveze zatvorenicima s naslova zatvaranja u istražnom postupku, pravomoćne sudske presude na kazne zatvora i supletorne kazne, kao i zatvorenicima povratnicima ${ }^{51}$ te zatvorenicima u pripremi za deportaciju. Za maloljetne i mentalno oboljele zatvorenike definirana su posebna pravila. Ovim propisom obuhvaćena je klasifikacija zatvorenika, stupanj zajedničke interakcije zatvorenika i kontakti s izvanjskim svijetom; medicinska, socijalna njega i dušobrižništvo; rekreacija, rad i disciplina, odnosno cjelokupni sustav izvršenja kazne zatvora. Kazne zatvora te mjere istražnog zatvora izvršavaju se u kaznenim institucijama ili sudjelovanjem u posebnim programima (izvan samih institucija). Prema dokumentu, zatvorske institucije dijele se na zatvore, kaznionice te institucije za prijestupnike-povratnike. ${ }^{52}$

Klasifikacija zatvorenika vrši se, uz kriterij spola, i prema kriteriju sigurnosti (rizik od bijega). Dob i duljina kazne donošenjem Zatvorskih pravila 1998. godine više ne predstavljaju formalne kriterije, ali su ostali u praksi. Iako klasifikacija prema spolu pretpostavlja razdvajanje zatvorenika i zatvorenica u zasebna krila (ako su smješteni u istoj ustanovi), moguće su zajedničke aktivnosti. Navedeni kriterij sigurnosti determinira klasifikaciju zatvorskih institucija (kao zasebnih cjelina ili izdvojenih krila) i to kroz pet razina: izrazito niske, niske, srednje, visoke i izrazito visoke sigurnosti. Razine predstavljaju nivelaciju sigurnosnih karakteristika otvorenog, poluotvorenog i zatvorenog tipa zatvora. Upućivanje, kao i naknadni transfer zatvorenika, rezultat je selekcije koja se temelji na kriteriju rizika. Kriterij se utvrđuje profiliranjem individue i njegove kriminalne prošlosti, pripadnosti zabranjenim organizacijama, financijskim stanjem, ali i odnosom prema drugim zatvorenicima. Procedura napredovanja kroz zatvorske razine uglavnom počinje u zatvorenom tipu. Ovisno o ponašanju i zalaganju, zatvorenik može napredovati brže, sporije ili može stagnirati u procesu postupnog stjecanja povlastica i slobode..$^{53}$

\subsubsection{Kategorija izrazito visoke sigurnosti}

Ovaj tip institucije pretpostavlja potpunu infrastrukturnu izolaciju od izvanjskog svijeta. Visoki zidovi, zasebne ćelije, stroge kontrole ćelija i posjetitelja te zabrana interakcije sa za-

50 Treba napomenuti kako, resocijalizacija kao precizirana svrha izvršavanja kazne zatvora, do danas je vidno izgubila na snazi. Prema Boone, ona se više ne smatra sferom isključive odgovornosti implementacije od strane političkih vlasti i upravljačkih struktura zatvorskih institucija, nego je svedena na dispozitivnu kategoriju čija implementacija ovisi o isključivoj motivaciji zatvorenika. S tim u vezi, možemo konstatirati kako je upitna jedinstvenost i sukladnost legislativnih i političkih ciljeva. Boone, M., Kox, M., What works for irregular migrants in the Netherlands?, European Journal of Probation , University of Bucharest, Vol. 4, No. 3, 2012, str. 54-68, ISSN: 2006-2203, str. 55. Dostupno na: URL= http://www.ejprob.ro/uploads-ro/777/Irregularmigrants-in-The-Netherlands-final.pdf.

51 Persistent offenders predstavljaju specifičnu skupinu zatvorenika - recidivista iz sfere sitnog kriminala (zbog počinjenih kaznenih dijela zapriječene kazne zatvora do četiri godine, ponovljenih minimalno tri puta unatrag pet godina s vjerojatnošću ponavljanja i u budućnosti) koji se smještaju u posebne zatvorske odjele(s posebnim programom) u sklopu provedbe mjera institucionaliziranja prijestupnika-povratnika, odnosno ISD (Inrichting Stelselmatige Daders) mjera. Mjera se određuje odlukom suda, na prijedlog javnog tužitelja, ali nije usmjerena na kažnjavanje prijestupnika. Dvostruka svrha mjere usmjerena je na odstranjivanje društvene smetnje (nuissance) radi zaštite društva te fizičko onemogućavanje, odnosno prekidanje negativnih navika prijestupnika koje su najčešće uzrokovane nekim oblikom ovisnosti. Mjera se određuje u trajanju od dvije godine, iznimno jednu godinu. Pitanje ozbiljnosti trajanja mjere zatvaranja opravdano je nemogućnošću provedbe bilo kakvog ozbiljnijeg rehabilitacijskog programa u kraćem periodu. 
tvorenicima drugih odjela predstavljaju glavna obilježja. Potreba za ovakvim zatvorom, navodi Tak, ${ }^{54}$ pojavila se nakon nekoliko slučajeva bijega izuzetno opasnih kriminalaca devedesetih godina prošloga stoljeća. Nakon prvotnog otvaranja ovakvih odjela u sklopu pojedinih zatvora, došlo je do izgradnje Nieuw Vosseveld u mjestu Vught, koji zapravo predstavlja jedan veliki odjel unutar regularnog zatvora zatvorenog tipa s 18 ćelija namijenjenih zatvorenicima visokog rizika. Zatvorenici posljednjih 18 mjeseci svoje kazne moraju izdržavati u instituciji niže kategorije sigurnosti.

\subsubsection{Kategorija visoke sigurnosti}

Institucije visoke sigurnosti primaju asocijalne i izrazito nasilne zatvorenike. Manipulativni i subverzivni pojedinci koji predstavljaju opasnost za društvo podvrgavaju se posebnim preventivnim programima individualnog pristupa. Primjer takvih sigurnosnih parametara nalazimo u krilima zatvora u Rotterdamu i Vughtu koji su namijenjeni zatvorenicima osuđenima za terorističke akte. ${ }^{55}$ Sprječavanje fundamentalističke infekcije ostalih zatvorenika objašnjava njihovo smještanje u zasebna krila.

\subsubsection{Kategorija srednje sigurnosti}

U ovaj tip institucije u pravilu dolaze uhićene osobe koje se nisu odazvale pozivu na odsluženje kazne zatvora ${ }^{56}$ ili osuđenici kojima je preostalo tri mjeseca zatvorske kazne, a nisu konfliktnog karaktera niti postoji opasnost od interakcije s drugim osuđenicima.

\subsubsection{Kategorija niske sigurnosti}

U institucije niske sigurnosti, prema Tak, ${ }^{57}$ dolaze dvije skupine zatvorenika. Jedna je na kraju izdržavanja svoje duge kazne, odnosno posljednjih 6 do 18 mjeseci, dok drugu skupinu čine osuđenici s tzv. liste čekanja (waiting list), koji su se odazvali pozivu na odsluženje zatvorske kazne (u pravilu kraćoj od dvije godine). Zatvorenici upućeni u ovaj tip zatvora u pravilu ne predstavljaju prijetnju društvu niti postoji evidentan rizik od bijega. Naprotiv, u ovoj kategoriji sigurnosti zatvorenici ostvaruju povlasticu poput vikend otpusta.

54 Ibidem, str. 144.

55 Iako Zatvorska pravila kao temeljni akt definiraju rehabilitaciju kao svrhu kazne zatvora, to se ne odnosi i na tzv. teroristička krila, odnosno zasebna krila namijenjena osuđenicima zbog terorističkih akata. Štoviše, na pitanje o rehabilitaciji terorista, Ministar pravosuđa je jasno odgovorio kako rehabilitacija nije programski zadatak krila namijenjenih teroristima. Vidi Veldhuis, T., Prisoner Radicalization and Terrorism Detention Policy: Institutionalized Fear Or Evidence-Based Policy Making?, Routledge, 2016, str. 40. Dostupno na: URL= https://books.google.hr/books?id=xxfX18-pvUYC\&pg=PA253\&lpg=PA253\&dq=Penitentiary+ Principles+Act andr ehabilitation\&source=bl\&ots=7zmwVhbJl\&sig=pRknI6c28z6QgdIzK6e2XqA8s0\&hl=hr\&sa=X\&ved=0ahUKEwiGz86WiJTYAhUFbVAKHW5BCwQ6AEIbDAJ\#v=onepage\&q=Penitentiary\%20Principles\%20Act\%20and\%20rehabilitation\&f=false.

56 Smještanje osuđenika s tzv. liste čekanja u zatvor kategorije srednje sigurnosti predstavlja način sankcioniranja onih osuđenika koji su pokušali izbjeći izvršavanje kazne zatvora, odnosno nisu se odazvali pozivu na odsluženje izrečene kazne zatvora, čije bi odsluženje inače započeli u zatvoru niže sigurnosne kategorije. 


\subsubsection{Kategorija izrazito niske sigurnosti}

Svrha ovakvog tipa institucije ogleda se u potrebi za institucijom minimalnog osiguranja i maksimalne implementacije resocijalizacijskog programa kroz obrazovanje, rad i aktivniju interakciju s izvanjskim svijetom radi prilagodbe zatvorenika na uvjete života izvan zatvora. Ovaj stupanj sigurnosti katkad predstavlja posljednju fazu zatvoreničkog života zatvorenicima iz ustanova jačih mjera osiguranja. Osim formalnih pretpostavki koje se odnose na duljinu odslužene i preostale kazne zatvora, najvažniji preduvjeti služenja kazne zatvora u ovakvoj instituciji odnose se na nepostojanje rizika od bijega i apsolutnu psihosocijalnu stabilnost pojedinca.

\subsection{IZVRŠAVANJE KAZNE ZATVORA}

Kazna zatvora u pravilu se izvršava skupno, što podrazumijeva dijeljenje ćelija, prostorija za dnevni boravak kao i zajedničko participiranje u aktivnostima i obvezama, dok se noć provodi u ćelijama. Nizozemski zatvori podrazumijevaju tri režima slobode, što izravno ovisi o stupnju socijaliziranosti zatvorenika i spremnosti na normalan suživot s ostalim zatvorenicima:

1. neograničena sloboda interakcije

2. ograničena sloboda interakcije

3. individualni režim.

Neograničena sloboda interakcije pruža zatvorenicima mogućnost sudjelovanja u radu, vjerskim obredima, objedovanju, rekreaciji i sportu te programskim aktivnostima s ostalim zatvorenicima. Zatvorenici u ovom režimu provode na tjedan minimalno 59 sati izvan ćelija, s mogućnošću participiranja u rekreacijskim, sportskim i drugim aktivnostima u rasponu od 18 do 63 sata na tjedan. Režim ograničene slobode interakcije stavlja restrikcije na zajedničke aktivnosti; zatvorenici u ovom režimu ograničeni su na rad, vjerske obrede i fizičke aktivnosti na svježem zraku, s iznimnim participacijama u programima i aktivnostima. Individualni režim podrazumijeva ostvarivanje zatvoreničkih prava u izolaciji od ostalih zatvorenika. Dnevni raspored nije fiksiran i podložan je izmjenama.

Zatvorenici u pravilu objeduju u svojim ćelijama, dok se u otvorenim tipovima institucija dopušta, uz skupno objedovanje, čak i priprema hrane. Smješteni većinu svog vremena u ćelijama, zatvorenici imaju, ovisno o režimu, pravo izaći na svježi zrak u trajanju od minimalno jednog sata na dan. Knjižnice nude mogućnost čitanja knjiga i časopisa, slušanja glazbe i igranja računalnih igara, a postoji i mogućnost umjetničkog izražavanja zatvorenika u prostorijama za slikanje. Sport je uobičajena aktivnost. Zatvorenici mogu pod nadzorom obavljati telefonske pozive, participirati u grupnim sportovima i fitnesu. Rekreativni sadržaji nude mogućnost igranja šaha ili biljara te druženja. Dok pritvorenici nemaju obvezu sudjelovanja u radu (ali mogu ako žele), zatvorenici imaju obvezu raditi u sklopu svojih programa, unutar zatvora ${ }^{58}$ ili

58 Participiranje u radu, osim što donosi određena materijalna sredstva zatvorenicima, u nekim slučajevima može dovesti i do profesionalne prekvalifikacije zatvorenika, a kao najzastupljenije struke javljaju se kuhanje i obrada metala. Velika većina zatvorenika radi i do 20 sati na tjedan. Vidjeti: Report to the Government of the Netherlands on the visit to the Netherlands carried out by the European Committee for the Prevention of Torture and Inhuman or Degrading Treatment or Punishment (CPT) from 2 to 13 May 2016., CPT/Inf (2017) 1, Strasbourg, January 2017., str. 23. Dostupno na: URL= https://rm.coe.int/16806ebb7c. 
izvan njega, uglavnom za tvrtke koje surađuju s institucijom..$^{59} \mathrm{U}$ pravilu, zatvorenici otvorenog tipa zatvora rade izvan, dok oni u zatvorenom tipu rade unutar same institucije. Tradicionalni koncept zatvorske proizvodnje radi profita gotovo je u potpunosti napušten zbog financijske neisplativosti, ali i činjenice jačanja zaštite ljudskih prava koja zabranjuje izrabljivanje i prisilni rad. ${ }^{60}$ Svojim radom zatvorenici mogu zaraditi novac te kupovati dodatne prehrambene proizvode, duhan, pravo na TV prijamnik i sl. Zatvorenici koji su obvezni raditi, a to odbiju, potpadaju pod sankcije institucije koje mogu rezultirati izolacijom ili restrikcijom posjeta. ${ }^{61}$

Svi zatvorenici podvrgnuti su određenom programu izvršavanja kazne zatvora. Najveći broj zatvorenika spada pod standardne programe dnevnog rada bez dodatnih obrazovnih mogućnosti, osim ako nije riječ o iskazanoj motivaciji pojedinog zatvorenika. Redukcija ponude programa namijenjenih zatvorenicima jasno ukazuje na otklon od prvotne ideje rehabilitacijskog pristupa; naime, redefiniranje ličnosti zatvorenika zamjenjuje logika osposobljavanja zatvorenika za kvalitetniji i društveno prihvatljiviji život nakon izdržavanja zatvorske kazne. ${ }^{62}$ Programi osnovnih potreba primjenjuju se na zatvorenicima osuđenima na kratkotrajnu kaznu zatvora, a odnose se isključivo na radne aktivnosti. Programi individualnog nadzora namijenjeni su asocijalnim i agresivnim pojedincima koji se ne mogu uklopiti u zatvorska pravila i populaciju, a karakterizira ih stalna kontrola i individualni rad sa zatvorenikom. Rehabilitacijski programi za ovisnike započinju detoksikacijom zatvorenika, a završavaju njegovom integracijom u društvo. Redefiniranje osobnosti ovisnika predstavlja jedan od najtežih zadataka, a veliku ulogu igra i oštra kontrola krijumčarenja droge u same institucije. Zatvorenici u pripremi za deportaciju prolaze specifične programe radi osposobljavanja za povratak u svoju domovinu.

Posebni programi (tzv. Penitentiary progams) namijenjeni su zatvorenicima kratkotrajnih zatvorskih kazni (do tri mjeseca), koji kaznu mogu izdržati izvan institucije, kako bi se spriječilo narušavanje radnih i obiteljskih odnosa, ali moraju sudjelovati u određenim procesima i aktivnostima same institucije. Specifičan oblik ovakvog programa odnosi se na zatvorenike koji su osuđeni na minimalno šest mjeseci zatvorske kazne, a koji (ako ne predstavljaju rizik za društvo, ako su dobrog vladanja i nepostojećeg rizika od recidiva) posljednju fazu svoje ka-

59 Custodial Institutions Agency, op. cit. (bilj. 45), str. 9.

6o Obvezni rad u zatvorima nema karakter aktivne prisile u smislu sankcioniranja odbijanja rada, niti ima za cilj profit zatvorskih institucija. Vrednovanje zalaganja zatvorenika u ocjeni njegova generalnog ponašanja, mogućnost zarade i kupnje materijalnih dobara, stjecanje znanja i dnevna preokupacija predstavljaju suptilnu, pasivnu prisilu kojom se zatvorenici involviraju u radnu svakodnevicu. Neovisno o općepoznatim pozitivnim učincima rada na psihičko i fizičko stanje zatvorenika, a samim tim i na atmosferu mira i sigurnost među samim zatvorenicima i čuvarima, svjedočimo tipičnoj antinomiji teorije (ljudskih) prava i implementaciji istih. Činjenicu obveznosti rada zatvorenika kao zadiranje u njegovo teoretski elementarno ljudsko pravo neometanog egzistiranja unutar zatvorskih institucija kao čina izdržavanja kazne zatvora, nadjačava praktična potreba zatvorskog sustava, ali i društva, za konkretnom, benevolentnom i rehabilitacijski pozitivnom preokupacijom zatvorenika tijekom izdržavanja kazne zatvora. Riječ je, naime, o tipičnom nadjačavanju teoretske pravne logike od strane realnih potreba stvarnog života.

61 Tak, op. cit. (bilj. 25), str. 149.-151.

62 Motivacija zatvorenika predstavlja uvjet programima, osim kada je riječ o pitanju ovisnosti. Ali, institut rehabilitacije centralna je figura i prioritet u normativnom uređenju izvršavanja kazne zatvora, a involviranost u programe mehanizam provedbe tog instituta. Riječ je zapravo o najslabijoj točki rehabilitacijskih napora. Generalno gledano, ono od čega je nizozemski zatvorski sustav odustao (iako se u konkretnom primjeru govori o kratkotrajnim zatvorskim kaznama) jest tendencija rehabilitacije ličnosti zatvorenika; svoj fokus okrenuo je u smjeru izobrazbe korisnim vještinama i znanjima, radi lakšeg postpenalnog snalaženja na tržištu rada, što se pokazalo jako bitnim faktorom u borbi sa stopom recidivizma jer posao predstavlja temelj elementarnih društvenih procesa. To skretanje fokusa rezultat je dugogodišnjeg istraživanja učinaka rehabilitacije: kratkotrajne zatvorske kazne onemogućavaju kvalitetniju provedbu rehabilitacijskog pristupa, dok dugogodišnji zatvorenici sami po sebi najčešće imaju nekorigibilne poremećaje ličnosti, pojačane učincima dugogodišnjeg zatvaranja. 
zne mogu izdržati na slobodi, kod kuće ili u centru za rehabilitaciju. Kombinacija aktivnosti i rada uz nadzor probacijskih službenika i uz pomoć elektroničkog praćenja, naglasak stavljaju na resocijalizaciju i uspješan povratak prijestupnika u društvo. No, treba napomenuti kako implementacija ovakve vrste programa izravno ovisi o volji upravitelja zatvora. ${ }^{63}$

Programi za prijestupnike-povratnike (persistent offenders) u sklopu ISD mjere (Inrichting voor stelselmatige daders) pokazali su posebne rezultate. Zbog specifičnosti zatvoreničke populacije, čija je kriminalna navika uvjetovana nekim oblikom ovisnosti (u manjem broju psihičkim poremećajima), sama činjenica fizičke izolacije u instituciji omogućava lakšu provedbu detoksikacijskog procesa i odmak od sfere sitnog kriminala. Primjena standardnih programa rehabilitacije kroz rad, edukaciju, reafirmaciju samopoštovanja te financijskih i socijalnih vještina uz eliminaciju ovisnosti, pokazala je uspješnije rezultate od regularnih zatvorskih programa primijenjenih na recidiviste. Prema istraživanju Dokumentacijskog i istraživačkog centra Nizozemske (WODC), među zatvorenicima koji su prošli ISD mjeru bilo je $10 \%$ manje recidivista u odnosu na prijestupnike-povratnike koji su bili obuhvaćeni standardnim zatvorskim programima. ${ }^{64}$

\subsubsection{Eksperimentalni oblici izdržavanja kazne zatvora}

Početkom 21. stoljeća u Nizozemskoj razvijen je eksperimentalni oblik izdržavanja kazne zatvora pod nazivom Detention Concept Lelystad. ${ }^{65}$ DCL zatvor specifičan je po maksimalnoj aplikaciji visoke tehnologije radi kontrole i sigurnosti, drastično smanjenog broja djelatnika i proširene ponude dnevnih programa. Oblika kormila, institucija se dijeli na pet odjeljaka po pet ćelija. Svaka ćelija, prostora 55 kvadratnih metara, prima šest zatvorenika. Koncept razdvajanja temelji se na rotaciji odjeljaka, tako da se grupe zatvorenika različitih odjeljaka zapravo nikad ne sretnu u dnevnim aktivnostima. Ukupno 150 zatvorenika kontrolira samo šest zatvorskih čuvara, u grupama po dvoje, u tri segmenta: kontrolna soba, radne aktivnosti i rekreacija. Zatvorenici nose elektroničke narukvice koje služe, osim za praćenje, i pristupanju sustavu komunikacije preko touch-screen monitora. Monitori se nalaze na svakom krevetu, a zatvorenici mogu na njima gledati televiziju, naručivati posebnu hranu, telefonirati, prijavljivati se za aktivnosti, planirati posjete ili ugovarati zdravstvene preglede. Elektronički nadzor agresije preko frekvencije glasa također je implementiran. Nadzornici mogu u svakom trenutku spriječiti nasilje kojem prethodi verbalni konflikt, a koji alarmira čuvare u nadzornoj sobi. Svaka ćelija ima mikrovalnu pećnicu, perilicu za posuđe i rublje, zaseban tuš i sanitarni čvor, a zatvorenici su u obvezi ćelije držati čistima i urednima. Ćelije su otvorene od 8:45 do 12:15 te od 13:15 do 17:00 sati. Zatvorenici mogu svakodnevno birati aktivnosti sporta, rekreacije, edukacije, zajedničkog čišćenja. Edukacija i zajedničke akcije čišćenja obvezne su tri puta na tjedan. Sustav nagrada temelji se na pogodnostima poput telefonskih impulsa, duhana, samostalne sobe na jednu noć, dodatnih posjeta i sl. ${ }^{66}$ Osim eksperimentalnog karaktera sigurno-

\footnotetext{
63 Tak, op. cit. (bilj. 25), str. 142.-143.

64 Tollenaar, N.; Laan, A. M.; Beijersbergen, K. A., Short and long-term effects of the ISD measure, 2014. Dostupno na: URL= https:// english.wodc.nl/binaries/cahier-2014-10-summary-tcm29-72941.pdf.

65 U nastavku: DCL.

66 Tak, op. cit. (bilj. 25), str. 151.-153.
} 
snih aspekata institucije, intencija ovakve organizacije života zatvorenika okrenuta je razvijanju individualne odgovornosti i elementarnih životnih navika u sklopu dnevnih obveza. ${ }^{67}$

\subsection{OSTALE INSTITUCIJE POD NADZOROM AGENCIJE}

Osim zatvorskih ustanova, pod izravnim nadzorom Agencije nalaze se i kazneno-popravne institucije za maloljetnike, zatvorske bolnice te centri za prihvat imigranata. ${ }^{68}$

\subsubsection{Kazneno-popravne institucije za maloljetnike}

Maloljetni počinitelji kaznenih djela mogu biti institucionalizirani, ovisno o svojim godinama, na maksimalno dvanaest mjeseci (stariji od dvanaest, a mlađi od petnaest godina), ili dvije godine (stariji od 15, a mlađi od 18 godina). Sud može ostanak produljiti, ali maloljetni počinitelj ne smije biti u popravnoj instituciji dulje od šest godina. Kazneno-popravne institucije imaju dva stupnja slobode, kontrole, povlastica i mogućnosti: zatvoreni i poluotvoreni tip. Maloljetni prijestupnici u pravilu polaze od zatvorenog režima. Naglasak je na popravljanju i resocijalizaciji što se ostvaruje planskom implementacijom programa bihevioralne intervencije, edukativnih programa, postupnog popuštanja restrikcija i konačne, kontrolirane reintegracije u društvo. ${ }^{69}$

\subsubsection{Zatvorske bolnice}

Zatvorske bolnice, uz čitavu mrežu institucija namijenjenih psihijatrijskom i somatskom liječenju, pružaju usluge skrbi zatvorenicima tijekom i nakon izdržavanja zatvorske kazne. Psi-

67 Rezultati ovakvog pristupa zatvaranja prilično su interesantni. Zbog visokog stupnja digitalizacije, elektronički sustav se nije pokazao najstabilnijim, što je zapravo glavna zamjerka instituciji. Među zatvorskom populacijom odlazak u DCL smatran je povlasticom. Mali broj zatvorskih čuvara omogućio je koheziju i povezanost, samim tim i učinkovitije obavljanje radnih zadataka. Sustav tjednih bonusa motivirao je zatvorenike na bolje ponašanje, a diskrecija elektroničkog nadzora pojačala je osjećaj sigurnosti i minimalizirala tipičan zatvorski osjećaj ugroze prisutnošću čuvara. Suradnja sa zatvorskim čuvarima najbolje se ogleda u činjenici kako su zatvorenici zapošljavani i kao konsijerži, što je kao pozicija donosila bolja novčana primanja. Utjecaj na uspjeh ovakvog sustava u pogledu sigurnosti i smirenosti zatvorenika ogleda se u praksi vraćanja problematičnih zatvorenika u matične zatvorske institucije. Projekt, ako izuzmemo probleme s digitalnom infrastrukturom, pokazao se uspješnim u smislu sigurnosti zatvorenika i osoblja, ali i rentabilnosti u odnosu na standardnu zatvorsku instituciju. Navedeni primjer je tipičan dokaz na koji način tehnologija, ako se ispravno primjeni, može u procesu izvršavanja kazne zatvora minimalizirati negativne učinke koji narušavaju ionako krhke rezultate rehabilitacijskih programa. Vidi Kenis, P.; Kruyen P. M.; Baaijens J.m Barneveld, P., The Prison of the Future? An Evaluation of an Innovative Prison Design in the Netherlands, The Prison Journal, SAGE Publications, 2010. Dostupno na: URL= https://www.researchgate.net/public ation/228428104 ThPrisonoftheFutureAnEvaluat ionofanInnovative-Prison-Design-in-the-Netherlands.

Jelmer Brouwer, u svom tekstu na blogu stranice Sveučilišta u gradu Leidenu, ispravno uočava problem sa strancima. Naime, postavlja se pitanje što je sa strancima koji su osuđeni za kazneno djelo? Za njih, navodi autor, postoji poseban zatvor u nizozemskom gradu Ter Apelu. Stranci-zatvorenici nemaju pravo na programsku rehabilitaciju, a proces ide u smjeru deportiranja nakon izdržavanja zatvorske kazne. Autor ispravno adresira problem u smjeru Zatvorskih pravila koja, barem u teoriji, jamče rehabilitacijski pristup svim zatvorenicima kao svrhu izdržavanja kazne zatvora. Ovako, dvosmjernost se čini sastavnim dijelom nizozemske penalne politike, u kojoj se određeni prijestupnici nastoje vratiti i zadržati u društvu, dok se drugi izoliraju od istog. Brouwer, J. Punishing foreign national prisoners: deportation instead of resocialisation?, Leiden Law Blog, University of Leiden, 2017. Dostupno na URL http://leidenlawblog.nl/articles/punishing-foreign-national-prisoners-deportation-instead-ofresocialisati on. 
hijatrijsko liječenje u Nizozemskoj obavlja se u dvjema centralnim vladinim i deset privatnih institucija (koje su pod kontrolom Agencije), četirima zatvorskim psihijatrijskim centrima te 102 standardne medicinske institucije u kojima se može aplicirati za pojedine tretmane, standardnu te intenzivnu njegu. Posebni medicinski zahvati obavljaju se u regularnim bolnicama. Unutar zatvora postoje odjeli za njegu i osnovnu medicinsku skrb, psihijatrijske ambulante te četiri zatvorska psihijatrijska centra. Za potrebe osuđenika izvan samih zatvorskih institucija postoje psihijatrijske bolnice i smještajni kapaciteti (kuće) te klinike za odvikavanje. Nakon izdržane kazne zatvora na raspolaganju potrebnim tretmanima stoje psihijatrijski centri i ambulante, kao i bolnice te ambulante opće medicine. ${ }^{70}$

\section{ZAKLJUČAK}

Nizozemski zatvorski sustav nesumnjivo je prošao kroz određene promjene unatrag nekoliko desetljeća. Rezultat oporavka od zatvorske krize nije ostvaren bez posljedica. Erodirana uloga načela rehabilitacije u odnosu na sedamdesete godine 20. stoljeća te potpuno zaobilaženje tretmana pojedinih skupina (imigranti i teroristi), ukazuje na promjenu smjera provedbene politike u penitencijarnom sustavu. Zatvori zadržavaju funkciju protekcije društva od relativno malog broja opasnih skupina i zločinaca, dok velikoj većini ostalih zatvorenika zatvor predstavlja prijelaznu instituciju. Naglasak na kontroliranoj, ali snažnoj fluktuaciji najvećeg broja zatvorenika, uz reduciranje ponuđenih institucionalnih programa i sadržaja, ukazuje na moguće transpozicioniranje pojedinih elemenata rehabilitacijskih napora u smjeru mehanizama izvan samih institucija, i to u onoj mjeri koja je potrebna za zadovoljenje elementarnih potreba nakon izdržavanja kazne zatvora. Intenzitet izricanja minimalnih kazni zatvora zadovoljava društveni zahtjev za kažnjavanjem prijestupnika, a sve to uz minimalno financijsko opterećenje sustava, što je u skladu s političkim zahtjevom stabilnosti i rentabilnosti sustava. $\mathrm{S}$ druge strane, involviranje suvremenih tehnoloških dostignuća u cjelokupan proces donosi pozitivne rezultate. Tehnologija pruža odlične uvjete razvoju eksperimentalnih zatvorskih projekata čiji rezultati otkrivaju nove mogućnosti u sferi humanizacije procesa izvršavanja kazne zatvora, ali i kontrole osuđenika izvan samih institucija. Imajući u vidu sve nedostatke nizozemskog zatvorskog sustava, nepobitna je činjenica kako je riječ o izuzetno funkcionalnom, rentabilnom i humanom zatvorskom sustavu, a eventualni probitci na polju penologije kao rezultat eksperimentiranja s modernim tehnologijama ne bi nas trebali iznenaditi jer u slučaju nizozemskog zatvorskog sustava to bi samo značilo ponavljanje povijesti.

70 Masthoff, E. D. M., Forensic psychiatric care and treatment in the Dutch Penitentiairy system, Custodial Institutions Agency. Dostupno na: URL= https://www.era-comm.eu/detention/pdf/314DT12-Masthof.pdf. 


\section{LITERATURA}

1. Beijerse, J., Swaaningen, R., Non-custodial sanctions, u: Dutch prisons (ur. Boone, M., Moerings, M.), BJu Legal Publishers, Den Haag, 2007.

2. Coyle, A., Upravljanje zatvorima u vremenu promjena, International Centre for Prison Studies, London, 2002.

3. Christie, N., Granice patnje, Pravni fakultet Beograd, Edicija Svetska pravna baština, Beograd, 2015.

4. Duker, M., Incapacitation: Trends and New Perspectives, Routledge, 2016.

5. Downes, D., Swaaningen, R., The Road to Dystopia? Changes in the Penal Climate of Netherlands, Crime and Justice, Vol. 35, No. 1, Crime and Justice in the Netherlands, 2007.

6. Howard, J., Stanje u zatvorima, Pravni fakultet Beograd, Edicija Svetska pravna baština, Beograd, 2015.

7. Ivičević Karas, E., Penitencijarno pravo, Narodne novine, Zagreb, 2016.

8. Snacken, S., Zyl Smit, D., Principles of European Prison Law and Policy: Penology and Human Rights, Oxford University Press, New York, 2009.

9. Swaaningen, R., Reversing the Punitive Turn: The Case of the Netherlands, European Penology, Hart Publishing, London, 2013.

10. Tak, J. P. P., The Dutch Criminal Justice System: Organization and operation, Wetenschappelijk Onderzoek-en Documentatiecentrum (WODC), Den Haag, 1999.

11. Tak, J. P. P., The Dutch Criminal Justice System, Wolf Legal Publishers, Nijmegen, 2008.

\section{MREŽNI IZVORI}

1. Briege, N., Life after Prison: Resettling Adult Offenders, Report, Glasgow, Scotland: April 2008. Dostupno na: URL= http://cep-probation.org/wp-content/uploads/2015/03/rep-Gla-08.pdf.

2. Brouwer, J., Punishing foreign national prisoners: deportation instead of resocialisation?, Leiden Law Blog, University of Leiden, 2017. Dostupno na: URL= http://leidenlawblog.nl/articles/ punishing-foreign-national-prisoners-deportation-instead-of-resocialisation.

3. Boone, M., Judicial Rehabilitation in the Netherlands: Balancing between safety and privacy, European Journal of Probation, University of Bucharest, Vol. 3, No.1, 2011, pp 63-78, ISSN: 2006-2203, p. 65. Dostupno na: URL= http://www.ejprob.ro/in deks .pl/judicial-rehabilitation-in-the-netherlandsbalancing-between-safety-and-privacy.

4. Boone, M.; Kox, M., What works for irregular migrants in the Netherlands?, European Journal of Probation, University of Bucharest, Vol. 4, No. 3, 2012, str. 54.-68., ISSN: 2006-2203, str. 55. Dostupno na: URL= http://www.ejprob.ro/uploads-ro/777/Irregular-migrants-in-The-Netherlands-final. pdf.

5. Council of Europe: Report to the Government of the Netherlands on the visit to the Netherlands carried out by the European Committee for the Prevention of Torture and Inhuman or Degrading Treatment or Punishment (CPT) from 2 to 13 May 2016., CPT/Inf (2017) 1, Strasbourg, January 2017. str. 23. Dostupno na: URL= https://rm.coe.int/16806ebb7c.

6. Custodial Institutions Agency, Den Haag: May, 2009. Službena stranica Ministarstva pravosuđa Kraljevine Nizozemske. URL=https://www.rijksoverheid.nl/documenten/ brochures/2010/09/30/ custodial-institutions-agency. 
7. Kenis, P.; Kruyen P. M.; Baaijens J.; Barneveld P., The Prison of the Future? An Evaluation of an Innovative Prison Design in the Netherlands, The Prison Journal, SAGE Publications, 2010. Dostupno na: URL=https://www.researchgate.net/publicati on/228428104The_Prison-of-the-Future-An-Evaluation-of-an-Innovative-Prison-Design-in-the-Netherlands.

8. Laffineur, J., Workstream 2 - National Reports - The Netherlands, CRID\&P Universite de Louvain, Belgique, str. 11. Dostupno na: URL=http://www.prisonlitigationnet work.eu/wp-content/uploads/2016/11/country-report-netherlands.pdf.

9. Masthoff, E.D.M., Forensic psychiatric care and treatment in the Dutch Penitentiairy system, Custodial Institutions Agency. Dostupno na: URL= https://www.era-comm.eu/detention/pdf/314DT12Masthof.pdf.

10. Multicultureel Nederland: Historyofimmigration in the Netherlands, University College London. URL= http://www.ucl.ac.uk/dutchstudies/an/SP-LINKS-UCL-POPUP/SPs-english/multicultureel-gevENG/pages/geschiedenisimm.html.

11. O'Connor, R., The United States Prison System: A Comparative Analysis, Graduate Theses and Dissertations, University of South Florida, 2014. Dostupno na: URL= http://scholarcommons.usf.edu/cgi/ viewcontent.cgi?article $=6282 \&$ context $=$ etd.

12. Sagel-Grande, I., Dutch Conditional Release for Prisoners as far as regulated by Law, Groningen University \& Association EuroMoS. Dostupno na: URL= http://www.exocop.eu/sixcms/media.php/13/ Dutch\%20Conditional\%20Release\%20for\%20Prisoners\%20in\%20a\%20Nutshell.pdf.

13. Simon, F., Prison work and social enerprise: the story of Barbed, 2005, The Howard League for Penal Reform. Dostupno na: URL= http://howardleague.org/wp-content/uploads/2016/05/Prison-work-and-social-enterprise.pdf.

14. Tollenaar, N.; Laan, A.M.; Beijersbergen, K.A., Short and long-term effects of the ISD measure, 2014. Dostupno na: URL=https://english.wodc.nl/binaries/cahier-2014-10-summary-tcm29-72941.pdf.

15. Službena stranica nizozemskog javnog tužiteljstva (Openbaar Ministerie), https://www.om.nl.

16. This is the Custodial Institutions Agency (DJI), Den Haag: June, 2015. Službena stranica Ministarstva pravosuđa Kraljevine Nizozemske. URL= https://www.dji.nl/binaries/lr-93324-ditisdji-en-v2-3tcm41-121757.pdf.

17. Tonry, M.; Bijleveld C., Crime, Criminal Justice, and Criminology in the Netherlands, 35. Crime\&Just. 1, 2007. Dostupno na: URL= http://scholarship.law.umn.edu/cgi/ viewcontent.cgi?article $=1505 \&$ context $=$ faculty-articles.

18. Veldhuis, T., Prisoner Radicalization and Terrorism Detention Policy: Institutionalized Fear Or Evidence-Based Policy Making?, Routledge, 2016, str. 40. Dostupno na: URL= https://books.google. $\mathrm{hr} /$ books?id=xxfX18-pvUYC\&pg=PA253\&lpg=PA253\&dq=Penite ntiary+Principles + Act + and + re habilitation\&source=bl\&ots=7zm_wVhbJl\&sig=pRknI6c28z6-QgdIzK6e2XqA8s0\&hl=hr\&sa=X\&ved=0ahUKEwiGz86WiJTYAhUFb VAKHW5-BCwQ6AEIbDAJ\#v=onepage\&q=Penitentiary\%20 Principles\%20Act\%20and\%20rehabilitation\&f=false.

19. Waard, J., Explaining the crime drop in The Netherlands: The importance of comparisons with other industrialised countries, 2015. Dostupno na: URL= https://www.researchgate.net/profile/Jaap_ De_Waard/publication/287759866-The-crime-drop-in-The-Netherlands-and-other-industrialized-countries-Trends-and-possible-explan ations/links/567922db08aeaf87ed8afad6.pdf?origin=publication-detail. 


\section{THE TURN IN THE CRIMINAL POLICY AND MODERN PRISON SYSTEM IN THE NETHERLANDS}

\section{Summary}

This paper deals with the prison system in the Netherlands in light of the current turn in criminal policy. By resolving the significant problem of threatening overcapacity in Dutch penitentiary institutions an answer is offered to the question that penologists have been asking for the past three decades: Are the prisons entering a new phase of their development and function? The personality of the prisoner and his psychosocial recuperation, as the absolute focus and historical determinant of the Dutch prisons' philosophy, fall into a subordinate position in public demands for the safety of the society as well as insisting of political structures on the reducing costs of the system. The coincidence of political demand for reducing the costs by applying modern technological achievements in the fields of supervision and control, for the first time in history, allows extensive application of extramural forms of punishment, which closes a transitional institution in the process of punishing the vast majority of prisoners, for whom intramural rehabilitation programmes are being reduced. Full and exclusive institutionalization is subjected to limited groups of prisoners convicted for the hardest criminal offenses. The paper deals with the historical background of social and political developments in the Netherlands that have determined the new direction of the penal policy, and thus the nature of the prisons. In the second part of the paper, the above course of research continues in the direction of thoroughly elaborating the ways of functioning and structure of the modern prison system in the Netherlands, with an overview of the functioning of standard and experimental forms of penitentiary programs.

Keywords: $\quad$ Dutch prison system, execution of prison sentences, shutting down prisons in the Netherlands, penitentiary programs

\section{(c) (1) (2)}

This work is licensed under a Creative Commons

Attribution-NonCommercial 4.0 International License.

* Zvonimir Tomičić, PhD, Assistant Professor, Chair of Criminal Law, Faculty of Law, Josip Juraj Strossmayer University of Osijek. Stjepana Radića 13, 31000 Osijek, Republic of Croatia. E-mail address: tomz@pravos.hr. ORCID: https://orcid.org/0000-00016159-6475.

** Vladimir Horvat, LLM. Residence: Glavna 64, 31309 Kneževi Vinogradi, Republic of Croatia. E-mail address: vladimir.horvat89@ gmail.com. ORCID: https://orcid.org/0000-0002-4269-7470. 